\title{
NOVEL APPLICATIONS OF INFRARED TECHNOLOGIES IN DAIRY INDUSTRY*
}

Massimo De Marchi**, Angela Costa, Arianna Goi, Mauro Penasa, Carmen L Manuelian

Department of Agronomy, Food, Natural resources, Animals and Environment, University of Padova, Italy

Dairy industry is economically relevant in many countries, and milk and its derived products are important sources of nutrients both in developed and developing countries. Thus, the dairy industry is interested in the application of rapid and cost-effective technologies for raw product evaluation, processing control and labeling. One of the most widespread technologies for milk and dairy product analysis is the infrared spectroscopy, mainly in the mid-infrared (MIRS) and near-infrared (NIRS) spectra regions. Other than standard composition, the assessment of milk technological traits is of particular interest in Europe and, traditionally, milk coagulation traits and acidity, milk protein and mineral composition have been determined using time-consuming laboratory methods. Recently, the development of specific MIRS prediction models for such milk traits has allowed the collection of coagulation information at herd and population level for milk quality payment and genetic selection purposes, respectively. Therefore, MIRS technology offers the possibility to conduct largescale phenotypic, genetic and genomic studies, even through a posteriori prediction using historical milk spectra stored in the laboratories. Cheese provides essential nutrients such as fatty acids, minerals and vitamins, and its consumption in Europe has grown in the last decade. Nevertheless, due to the negative consequences of the Western diet on the cardiovascular system mainly related to the excessive intake of saturated fatty acids and sodium, the declaration of salt and saturated fatty acids contents in the product's label has become mandatory. In the last years, the dairy industry has successfully developed and implemented NIRS prediction models for at-line and inexpensive quantification of minerals and fatty acids of commercial cheeses in order to quickly incorporate this information on the label of dairy products. The development of MIRS and NIRS prediction models for milk and cheese traits has opened new opportunities in the field of dairy products, spanning from genetic selection to technological efficiency.
(REVIEW PAPER) UDC 637.1:543.42

Keywords: infrared spectroscopy, milk, cheese, novel phenotypes, dairy industry

\section{Introduction}

The amount of delivered bovine milk and the export of cheese have increased in Europe, exceeding 156,000,000 and 800,000 tons in 2018, respectively [1]. From the nutritional point of view, dairy products are relevant sources of essential substances for human beings, providing omega-3 fatty acids, antioxidants, calcium, phosphorus and other bioactive compounds [2]. On average, a glass $(250 \mathrm{~mL})$ of whole bovine milk per day would cover 20 to $25 \%$ and $45 \%$ of the recommended calcium and vitamin B12 daily intake, respectively [3]. However, in bovine, milk characteristics may vary according to several factors such as breed, genetics, season, feeding system and animal health status [3]. In addition, the quality of milk directly affects some technological features related to cheese manufacturing $[4,5]$. Thus, fast and cost-effective routine analyses have become fundamental within the dairy chain to segregate the 'best milk' for the 'best use', i.e. for the manufacture of cheese, yogurt, beverages and other processed foods.

Infrared spectroscopy is currently the most adopted technology for fast and cheap analysis of foodstuffs, even in dairy. This technique exploits the electromagnetic reaction between radiation and matter and is based on the Beer-Lambert law. In particular, near- (NIRS) and midinfrared spectroscopy (MIRS) consider spectral regions from 800 to $2,500 \mathrm{~nm}$ and from 2,500 to $25,000 \mathrm{~nm}$, respectively. In addition to providing predictions of constituents concentration, MIRS and NIRS are able to detect

\footnotetext{
*The paper was presented at 13th Symposium with international participation "NOVEL TECHNOLOGIES AND ECONOMIC DEVELOPMENT" as a plenary lecture, Faculty of Technology in Leskovac,

18-19 October, 2019.

** Author adress: Massimo De Marchi, Department of Agronomy, Food, Natural resources, Animals and

Environment, University of Padova, Viale dell'Università 16, 35020 Legnaro (PD), Italy

E-mail: massimo.demarchi@unipd.it

The manuscript received: October, 03, 2019.
} 
adulterations (e.g. presence of milk of different species) and, in the era of precision livestock farming, are useful tools for genetic and management purposes since they provide large-scale data.

\section{The theory behind infrared spectroscopy}

Infrared spectroscopy is a technology that exploits the interaction between matter and electromagnetic waves, allowing the detection and quantification of elements, molecules or compounds. Briefly, a sample (e.g. milk or cheese) is subjected to infrared radiation that could either passes through the matrix or be reflected with a part of the wave absorbed. The radiation absorption involves transitions between vibrational energy levels causing a vibration of the chemical bonds, which differs according to the material's structure and it may also depend on the component concentration in the sample. The recorded signal is processed by the Fourier transform mathematical treatment in order to convert the information from an interferogram to absorbance values. Graphically, the absorbed (or transmitted) infrared light on the vertical axis and the wavelength on the horizontal axis could be represented in a spectrum. The whole spectrum, generally an average of few sub-spectra, can be recorded as $\log (1 /$ reflectance) if the device records the reflected radiation or $\log (1 /$ transmittance $)$ if the instrument detects the radiation transmitted through the sample. While NIRS spectra usually include overlapping absorption bands which are difficult to be assigned to a single chemical component, MIRS is based on fundamental vibration of the molecules which are stronger and should be potentially more informative than NIRS [6]. Moreover, MIRS allows accurate quantitative determinations of compounds because the absorption bands are proportional to the concentration of the functional groups [7].

The capacity of infrared spectroscopy to predict compounds is based on its response to rotational and vibrational energies of the hydrogen bonds; for instance, the most important absorption bands which occur in the nearinfrared region are related to $\mathrm{C}-\mathrm{H}, \mathrm{O}-\mathrm{H}, \mathrm{N}-\mathrm{H}$ and $\mathrm{S}-\mathrm{H}$ functional groups [8]. In other words, the electromagnetic radiation absorbed from molecular bonds of a substrate produces a 'fingerprint' in the form of spectra [9].

It is possible to obtain an indirect determination of inorganic constituents if they are able to produce alterations of the water spectrum; e.g. Ca, Mg, and P are part of organic complexes in casein micelles and are thus predictable in both milk and cheese $[10,11]$. However, the accuracy of prediction is lower for traits that are not directly linked to an absorption infrared region or to organic molecules, and whose reference values are obtained through a subjective evaluation, such as sensory traits in cheese [10]. In terms of accuracy, it is important to consider that the prediction model for the same trait can provide different results according to sample preparation, instrument used to collect spectra and wavelength range considered [12,13]. Furthermore, the greater the error of the reference analysis, which may be due to the number of steps taken for the chemical determination of the trait, the lower the prediction accuracy will be. [14].

\section{Chemometric}

Prediction models may be developed through different kinds of regression analyses. The partial least squares (PLS) regression analysis is a model which specifies the linear relationship between a predictor variable and one or several dependent variables (response). If the 'predictor' and the 'response' have nonlinear characteristics, the performance of the PLS is usually poor. This is why the Kernel PLS, a natural extension of PLS, should be adopted when dealing with nonlinear data [15]. For example, some authors reported better fitting statistics for Kernel PLS rather than for standard PLS regression, when predicting protein content in barley [16]. In addition, the modified PLS regression analysis is often considered more accurate than standard PLS, due to residual standardization within the regression algorithm $[17,18]$.

Prediction models can be developed using the complete dataset or using a subset ('calibration set'). It is important to collect samples that are representative of the entire target population to maximize variability and thus to accurately apply the model on future unknown samples.

The calibration is a regression model that uses spectral data as independent variables to obtain prediction of some chemical properties. Since spectra can show overlapping bands due to the physical or chemical complexity of the matrix and due to the fact that there is no a direct correlation between a single wavelength and a single property, a multivariate calibration is generally used to include several wavenumbers as predictors [9].

In the calibration procedure, outliers elimination can be performed to avoid presence of spectral data deviating from population distribution. For outliers' detection, a critical T-value is set (e.g. 2.5) to indicate the maximum deviation from the mean value allowed in terms of standard error of predicted values from the reference value. Software used to perform prediction models can automatically detect spectral outliers using different criteria. Before calibration, water absorption regions present in the spectra are removed to avoid interferences [9]. In particular, multiplicative scatter correction, standard normal variate, and detrending are widely used pre-processing techniques to drop noises, reduce variability between samples due to scatter and remove artifacts or imperfections from the data matrix before data modeling. Scatter correction is combined with mathematical treatments and it reads as follows: $0,0,1,1 ; 1,4,4,1 ; 1,8,8,1 ; 2,5,5,1 ; 2,10,10,1$; where the first digit is the number of the derivative, the second one is the gap over which the derivative is calculated, the third one is the number of data points in the first smoothing, and the fourth one is the number of data points in the second smoothing [19]. Although several combinations of scatter corrections and mathematical treatments are usually applied to find the most accurate prediction model, authors often report only the best combination.

Once the calibration has been performed, it is necessary 
to test the model. When the complete dataset is used for calibration, it can be validated through leave-one-out or fold cross-validation; on the other hand, if only a subset is used as calibration set, the model is tested in external validation on another subset or independent set. In the case of leave-one-out cross-validation a single sample is excluded in each iteration, which means that one sample is used as validation data and the remaining samples as training set. The process works in loop and thus, at the end, all the samples are used as validation data. The fold cross-validation consists of dividing the dataset into a certain number of folds, which are excluded one at a time in each iteration. However, for the performance of an external validation, the dataset should be divided into 2 subsets; the first (usually around $75 \%$ of samples) is used as calibration set and the second is the validation set obtained using the remaining $25 \%$ of the samples. Validation sets may be also external independent datasets. If the sample size is limited, cross-validation is preferable than external validation. The latter however is more appropriate to understand the prediction ability of the model when applied to samples with no reference values [20].

\section{Prediction accuracy}

The assessment of the predictive ability of a calibration model is based on the coefficient of determination $\left(R^{2}\right)$, that may refer to calibration accuracy or to validation accuracy, i.e. external $\left(R^{2} \mathrm{EV}\right)$ and cross validation $\left(R^{2} \mathrm{CV}\right)$. According to the technique used, it is calculated as the square of the correlation coefficient $(r)$ between the reference values and their corresponding predicted value. The overall prediction accuracy may be given by the standard error of calibration and validation; in fact, standard error decreases as the number of latent factors increases and thus is used to determine the number of latent factors. Moreover, predictive ability may be evaluated from the residual predictive deviation (RPD) of cross validation and external validation, that are calculated as the ration between standard deviation and standard error of cross- or external validation, respectively.

The interpretation of $\mathrm{R}^{2}$ has been widely described in literature [21]. Overall, $R^{2}$ between 0.66 and 0.81 indicates that the prediction equation is adequate only to obtain approximate predictions. If the $\mathrm{R}^{2}$ ranges from 0.82 to 0.90 , it could give a good estimation of the reference value. Finally, values $\geq 0.91$ indicate that the model could give an excellent estimation of the reference values. As regards interpretation of RPD [22], generally prediction equations with values $<2.3$ are considered very poor and not recommended for any application. Models with RPD from 2.4 to 3.0 are only feasible for rough screening, while accurate screenings may be obtained if RPD ranges from 3.1 to 4.9. Finally, prediction models with RPD from 5.0 to 6.4 and $\geq 6.5$ are considered good and excellent for quality control, respectively.

Why infrared spectroscopy

Thanks to the potentially high prediction accuracy, the non-invasive approach, the non-disruptive analysis and the relatively low initial investment, infrared spectroscopy has become popular in food industry and pharmaceutical sector for the reliable and indirect determination of product composition and characteristics [22,23]. In fact, MIRS and NIRS are objective methods and are easier to be managed compared with reference laboratory analyses; also, infrared spectroscopy allows the prediction of several traits simultaneously. These aspects are important in the era of food quality, where consumers' demand for healthy diet and certified production processes are increasing. In fact, industries are often obliged to certify the authenticity of the products, guaranteeing the standard requirements and ensuring nutritional adequacy for human health. This explains why the scientific research on this technology is running in different fields related to food science (Figure 1).

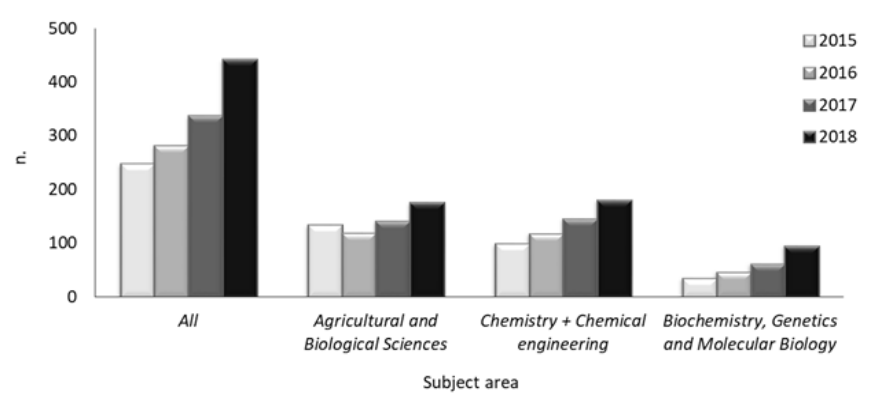

Figure 1. Number of papers, conference papers and review articles published between 2015 and 2018 mentioning simultaneously 'infrared', 'analysis' and 'food' in title or abstract (source: Scopus, 2019).

Moreover, among the advantages, infrared technologies may work in real time (in-line, on-line and at-line) to monitor food composition (or manufacture process). Whether the MIRS or NIRS device is located within the production chain, both in-line (without sampling and manipulation) and on-line analyses may be performed; in particular, the latter are carried out on representative selected samples taken from the line. On the other hand, at-line analyses are carried out on ready-to-sell products by food industry laboratories. Performing quality analyses during and/or after manufacture is thus helpful and necessary if optimization and adjustments have to be implemented promptly, i.e. by modifying the recipe and/or improving some product characteristics.

\section{Application of infrared spectroscopy in milk}

Milk major solids concentrations are predicted with high accuracy from individual bovine milk spectra. In fact, models installed in most common commercial MIRS devices, like MilkoScan (Foss Electric, Hillerød, Denmark), are characterized by $R^{2} \mathrm{CV}$ close to unity. Both milk payment systems of dairy industries (bulk milk) and the genetic evaluation of cattle (individual milk) rely on MIRSpredicted data. In particular, worldwide MIRS is accepted for milk analysis (fat, protein and lactose) of the official milk-recording schemes. In this view, infrared spectroscopy is an essential tool to ensure large-scale, accurate 
and fast collection of phenotypes.

Besides the traditional traits, MIRS has been used to predict other milk features such as casein concentration, urea content, fatty acids and protein composition, coagulation properties, antioxidant activity, acidity, minerals content, melamine content and ketone bodies [14], and cow characteristics (e.g. body weight, energy status, methane emission and residual feed intake) [24,25]. Milk coagulation properties are routinely predicted by few laboratories in Italy. These traits are currently combined in a selection index for 'cheeseability' in Italian Holstein and are also included in some Italian milk payment systems [26]. Milk total antioxidant activity has been predicted from milk spectra in different dairy species [27]; this feature may have positive impact on consumers' perception and thus the labeling would give an added value to the products. Recently, blood parameters have been predicted by MIRS from cow milk spectra [28], with $R^{2} \mathrm{CV}$ of 0.63 for beta-hydroxybutyrate and 0.52 for nonesterified fatty acids; both beta-hydroxybutyrate and nonesterified fatty acids are indicators of hyperketonemia and are useful to identify cows at risk of ketosis. Overall, there is currently no consensus on the ability of MIRS to predict cow methane emissions $[29,30]$, suggesting the need for further research. It is worth highlighting that cow characteristics (metabolic status, feed efficiency, etc.) are not directly measurable from the spectra of milk matrix itself, thus the prediction is not accurate enough to replace the gold standard. However, such data may be considered useful for large scale screening and will be essential to address breeding schemes at population level.

\section{Infrared spectroscopy in cheese}

One of the most complex matrixes for infrared analysis is cheese, due to the heterogeneity and variability of products and protocols [31]. So far, the prediction models developed were usually cheese-specific, i.e. explicitly intended for a cheese type or a category of cheeses [10]. Due to the lower amount of water compared to milk, cheese prediction models are usually built using wavelengths in the NIRS region, so that the sample does not need to be grinded or liquated [10]. Unfortunately, information on the practical applications and performances of NIRS in dairy factories is generally scarce, due to industrial secrecy policies.

Some studies reported that the predictive ability of MIRS device was better than that of NIRS instrument for cheese analyses, however, this may also be due to the different sample preparation required for the two devices. This was the case during determination of free amino acids in cheese using MIRS (ground sample) and NIRS (intact sample) [12]. Devices based on NIRS usually work in reflectance mode, like DS2500 (Foss Electric, Hillerød, Denmark), rather than in transmittance mode, like FoodScan (Foss Electric, Hillerød, Denmark). Regardless of that, the 2 modes are similar in terms of performance, as they showed similar accuracy of prediction of mineral content in soft cheeses [32].
Only few papers have dealt with traditional measures of gross composition of cheese, assessing moisture, fat and protein content, $\mathrm{pH}$, salt content, and nitrogen in different cheeses and ricotta $[16,33,34,35]$. However, in perspective, the major interest seems to be on the 'scarcely present' compounds and on 'difficult to predict' traits, i.e. not related to specific absorptions bands. Among these traits, minerals, fatty acids, cholesterol, volatile compounds and sensory properties stand out [10]. For example, some authors evaluated the potential of NIRS to predict the total antioxidant capacity of different cheeses, ending up with positive conclusions and perspectives [36]. Moreover, $\mathrm{R}^{2} \mathrm{EV}$ of 0.50 for cholesterol content has been reported [37]; as regards major minerals, the same authors found $\mathrm{R}^{2} \mathrm{EV}$ from 0.65 (potassium) to 0.94 (phosphorus). Nevertheless, the scientific community disclosed the limits of infrared techniques in predicting cheese sensory characteristics, such as pasty, grainy, solubility, cohesion, firmness on chewing, flavour intensity [12]. Furthermore, the potential and the limits of NIRS for volatile compounds prediction have been described [10]. Overall, for 'difficult to predict' traits the accuracy level of prediction models currently makes NIRS only useful for qualitative measurements, discrimination and classification. For example, NIRS may be able to i) detect adulterants, ii) discriminate between different species and breeds, iii) identify the animal rearing and feeding system, iv) estimate the ripening time, and v) distinguish the cheese brands [10].

In future, the focus will be on the prediction of cheese sodium content for low-salt cheeses; this would help dairy products to be listed as 'accepted food' for people suffering from cardiovascular diseases and high blood pressure.

\section{Infrared spectroscopy in other dairy matrices}

Both MIRS and NIRS are used for prediction of whey, yogurt and dairy powders composition. In particular, infrared spectroscopy can discriminate between brands of milk powder [38], assess infant formula quality [39] and predict composition [40] and level of protein hydrolysis in whey [41]. Moreover, the ability of MIRS/NIRS to detect adulterants and toxic substances in dairy matrixes has been investigated worldwide; infrared spectroscopy successfully identified infant formula samples with toxic levels of melamine [42].

\section{Conclusions}

Infrared technology has demonstrated its potential for large-scale data collection, process control, sample discrimination and prediction of quality traits in milk and cheese. The broad implementation of infrared technologies at the industry level depends on several factors such as the improvement of equipment designs (e.g. dimensions, robustness, easy-to-use), the reduction of the costs for the acquisition of devices, maintenance of calibration accuracy, and the increase of processing speed. 


\section{Abbreviations}

MIRS = mid-infrared spectroscopy; NIRS = near-infrared spectroscopy; $R^{2}$ = coefficient of determination; $R^{2} \mathrm{CV}$ $=$ coefficient of determination in cross validation; $R^{2} \mathrm{EV}=$ coefficient of determination in external validation; RPD = residual predictive deviation.

\section{References}

[1] CLAL. 2019. https://www.clal.it/en/?section=quadro_ europa. Accessed Sep. 20, 2019.

[2] Haug A, Høstmark AT, Harstad OM. Bovine milk in human nutrition - A review. Lipids Health Dis. 6 (2007) 25.

[3] Fox PF, Uniacke-Lowe T, McSweeney PLH, O'Mahony JA. Dairy Chemistry and Biochemistry. Seceond. Springer International Publishing, Basel, Switzerland, 2015.

[4] De Marchi M, Toffanin V, Cassandro M, Penasa M. Prediction of coagulating and noncoagulating milk samples using mid-infrared spectroscopy. J Dairy Sci. 96(7) (2013) 4707-4715.

[5] Toffanin V, De Marchi M, Lopez-Villalobos N, Cassandro M. Effectiveness of mid-infrared spectroscopy for prediction of the contents of calcium and phosphorus, and titratable acidity of milk and their relationship with milk quality and coagulation properties. Int Dairy J. 41 (2015) 68-73.

[6] Roychoudhury P, Harvey LM, McNeil B. At-line monitoring of ammonium, glucose, methyl oleate and biomass in a complex antibiotic fermentation process using attenuated total reflectance-mid-infrared (ATR-MIR) spectroscopy. Anal Chim Acta. 561 (2006) 218-224.

[7] Guillén MD, Cabo N. Infrared spectroscopy in the study of edible oils and fats. J Sci Food Agric. 75(1) (1997) 1-11.

[8] Roggo Y, Chalus P, Maurer L, Lema-Martinez C, Edmond $A$, Jent $N$. A review of near infrared spectroscopy and chemometrics in pharmaceutical technologies. J Pharm Biomed Anal. 44(3) (2007) 683-700.

[9] Prieto N, Pawluczyk O, Dugan MER, Aalhus JL. A review of the principles and applications of near-infrared spectroscopy to characterize meat, fat, and meat products. Appl Spectrosc. 71(7) (2017) 1403-1426.

[10] De Marchi M, Penasa M, Zidi A, Manuelian CL. Invited review: Use of infrared technologies for the assessment of dairy products-Applications and perspectives. J Dairy Sci. 101(12) (2018) 10589-10604.

[11] Büning-Pfaue $\mathrm{H}$. Analysis of water in food by near infrared spectroscopy. Food Chem. 82(1) (2003) 107-115.

[12] Kraggerud $H$, Næs T, Abrahamsen RK. Prediction of sensory quality of cheese during ripening from chemical and spectroscopy measurements. Int Dairy J. 34(1) (2014) 6-18.

[13] Margolies BJ, Barbano DM. Determination of fat, protein, moisture, and salt content of Cheddar cheese using midinfrared transmittance spectroscopy. J Dairy Sci. 101(2) (2018) 924-933.

[14] De Marchi M, Toffanin V, Cassandro M, Penasa M. Invited review: Mid-infrared spectroscopy as phenotyping tool for milk traits1. J Dairy Sci. 97(3) (2014) 1171-1186.

[15] Rosipal R, Trejo LJ. Kernel partial least squares regression in Reproducing Kernel Hilbert Space. J Mach Learn Res. 2 (2001) 97-123.

[16] Lin P, Chen YM, He Y, Hu GW, Fu XL, Gu CL. Study on Nonlinear Multivariate Methods Combined with the
Visible Near-Infrared Spectroscopy (Vis/NIRS) Technique for Detecting the Protein Content of Cheese. Food Bioprocess Technol. 7(12) (2014) 3359-3369.

[17] Meagher LP, Holroyd SE, Illingworth D, Van De Ven F, Lane S. At-line near-infrared spectroscopy for prediction of the solid fat content of milk fat from New Zealand butter. J Agric Food Chem. 55(8) (2007) 2791-2796.

[18] González-Martín I, Hernández-Hierro JM, GonzálezPérez C, Revilla I, Vivar-Quintana A, Lobos Ortega I. Potential of near infrared spectroscopy for the analysis of volatile components in cheeses. LWT - Food Sci Technol. 55(5) (2014) 666-673.

[19] Shenk JS, Westerhaus MO, Abrams S. Protocol for NIR calibrations: Monitoring analysis results and recalibration. In Near infrared spectroscopy for analysis of forage quality. Martens G, Shenk J, Barton F Ed. Washington, DC, US 1989, p. 104-110.

[20] Schmitt S, Garrigues S, de la Guardia M. Determination of the mineral composition of foods by infrared spectroscopy: A review of a green alternative. Crit Rev Anal Chem. 44(2) (2014) 186-197.

[21] Karoui R, Mouazen AM, Dufour E, Pillonel L, Picque D, Bosset $\mathrm{JO}$, et al. Mid-infrared spectrometry: A tool for the determination of chemical parameters in Emmental cheeses produced during winter. Lait. 86(1) (2006) 83-97.

[22] Yang H, Irudayaraj J. Rapid determination of vitamin $\mathrm{C}$ by NIR, MIR and FT-Raman techniques. J Pharm Pharmacol. 54(9) (2002) 1247-1255.

[23] Porep JU, Mattes A, Pour Nikfardjam MS, Krammerer DR, Carle R. Implementation of an on-line near infrared/visible (NIR/VIS) spectrometer for rapid quality assessment of grapes upon receival at wineries. 21(1) (2015) 69-79.

[24] Grelet C, Vanlierde A, Hostens M, Foldager L, Salavati $\mathrm{M}$, Ingvartsen $\mathrm{KL}$, Crowe $\mathrm{M}$, Sorensen MT, Froidmont E, Ferris CP, Marchitelli C, Becker F, Larsen T, Carter F, GplusE Consortium, Dehareng F. Potential of milk midIR spectra to predict metabolic status of cows through blood components and an innovative clustering approach. Animal. 13(3) (2019) 649-658.

[25] Mäntysaari P, Mäntysaari EA, Kokkonen T, Mehtiö T, Kajava S, Grelet C, Lidauer P, Lidauer $\mathrm{MH}$. Body and milk traits as indicators of dairy cow energy status in early lactation. J Dairy Sci. 102(9) (2019) 7904-7916.

[26] Pretto D, Lopez-Villalobos N, Penasa M, Cassandro M. Genetic response for milk production traits, somatic cell score, acidity and coagulation properties in Italian Holstein-Friesian population under current and alternative selection indices and breeding objectives. Livest Sci. 150 (2012) 59-66.

[27] Niero G, Penasa M, Costa A, Currò S, Visentin G, Cassandro M, De Marchi M. Total antioxidant activity of bovine milk: Phenotypic variation and predictive ability of mid-infrared spectroscopy. Int Dairy J. 89 (2019) 105-110.

[28] Benedet A, Franzoi M, Penasa M, Pellattiero E, De Marchi M. Prediction of blood metabolites from milk mid-infrared spectra in early-lactation cows. J Dairy Sci. (2019) in press.

[29] Shetty N, Difford G, Lassen J, Løvendahl P, Buitenhuis AJ. Predicting methane emissions of lactating Danish Holstein cows using Fourier transform mid-infrared spectroscopy of milk. J Dairy Sci. 100(11) (2017) 9052-9060.

[30] Wang Q, Bovenhuis $\mathrm{H}$. Validation strategy can result in an overoptimistic view of the ability of milk infrared spectra to predict methane emission of dairy cattle. J Dairy Sci. 
102(7) (2019) 6288-6295.

[31] Holroyd SE. The use of near infrared spectroscopy on milk and milk products. J Near Infrared Spec. 21(5) (2013) 311-322.

[32] Manuelian CL, Currò S, Penasa M, Cassandro M, De Marchi M. Characterization of major and trace minerals, fatty acid composition, and cholesterol content of Protected Designation of Origin cheeses. J Dairy Sci. 100(5) (2017) 3384-3395.

[33] Botelho BG, Mendes BAP, Sena MM. development and analytical validation of robust near-infrared multivariate calibration models for the quality inspection control of mozzarella cheese. Food Anal Methods. 6(3) (2013) 881891.

[34] Madalozzo ES, Sauer E, Nagata N. Determination of fat, protein and moisture in ricotta cheese by near infrared spectroscopy and multivariate calibration. J Food Sci Technol. 52(3) (2015) 1649-1655.

[35] Margolies BJ, Barbano DM. Determination of fat, protein, moisture, and salt content of Cheddar cheese using midinfrared transmittance spectroscopy. J Dairy Sci. 101(2) (2018) 924-933.

[36] Revilla I, González-Martín MI, Vivar-Quintana AM, Blanco-López MA, Lobos-Ortega IA, Hernández-Hierro JM. Antioxidant capacity of different cheeses: Affecting factors and prediction by near infrared spectroscopy. J Dairy Sci. 99(7) (2016) 5074-5082.
[37] Manuelian CL, Currò S, Penasa M, Cassandro M, De Marchi M. Prediction of minerals, fatty acid composition and cholesterol content of commercial cheeses by near infrared transmittance spectroscopy. Int Dairy J. 71 (2017) 107-113.

[38] Wu D, Feng S, He Y. Short-wave near-infrared spectroscopy of milk powder for brand identification and component analysis. J Dairy Sci. 91(3) (2008) 939-949.

[39] Wang X, Esquerre C, Downey G, Henihan L, O'Callaghan DJ, O'Donnell C. Assessment of infant formula quality and composition using Vis-NIR, MIR and Raman process analytical technologies. Talanta. 183 (2018) 320-328.

[40] Fagan CC, Castillo M, O'Callaghan DJ, Payne FA, O'Donnell C. Sensing and Instrumentation for Food Quality and Safety. 3(1) (2009) 62-69.

[41] Poulsen NA, Eskildsen CE, Akkerman M, Johansen LB, Hansen MS, Hansen PW, Skov T, Larsen LB. Predicting hydrolysis of whey protein by mid-infrared spectroscopy. Int Dairy J. 61 (2016) 44-50.

[42] Balabin MB, Smirnov SV. Melamine detection by midand near-infrared (MIR/NIR) spectroscopy: A quick and sensitive method for dairy products analysis including liquid milk, infant formula, and milk powder. Talanta. 85 (2011) 562-568. 
Izvod

\section{NOVE PRIMENE INFRACRVENIH TEHNIKA U INDUSTRIJI PRERADE MLEKA}

Massimo De Marchi, Angela Costa, Arianna Goi, Mauro Penasa, Carmen L Manuelian

Odeljenje za poljoprivredu, hranu, prirodne resurse, životinje i životnu sredinu, Univerzitet u Padovi, Italija

Industrija prerade mleka je od velike ekonomske važnosti u mnogim zemljama. Mleko i proizvodi od mleka predstavljaju važan izvor nutritijenata, kako u razvijenim tako i u zemljama u razvoju. Iz tog razloga, raste interesovanje industrije prerade mleka za primenom brzih i efikasnih tehnika za analizu sirovina, kontrolu procesa i označavanja. Infracrvena spektroskopija, naročito u oblasti srednjeg (mid-infrared - MIRS) i bliskog infracrvenog (near-infrared - NIRS) zračenja, predstavlja jednu od široko primenjivanih tehnika u analizi mleka i mlečnih proizvoda. Osim standardnih metoda za određivanje sastava mleka, procena njegovih tehnoloških karakteristika je od velikog značaja u Evropi. Osobine koagulacije mleka i kiselost, sadržaj proteina i prisustvo minerala u mleku se, tradicionalno, određuju primenom dugotrajnih laboratorijskih metoda. Nedavno, razvoj specifičnih MIRS modela za predviđanje pomenutih karakteristika mleka omogućio je prikupljanje informacija o koagulaciji mleka na nivou stada ili populacije u cilju određivanja kvaliteta mleka i genetičke selekcije, respektivno. Primena MIRS tehnologije pruža mogućnost sprovođenja fenotipskih, genetičkih i ekoloških studija velikih razmera, čak i na osnovu iskustvenog predviđanja upotrebom istorijske baze podataka spektara mleka. Sirevi obezbeđuju čoveku esencijalne nutritijente, kao što su masne kiseline, minerali i vitamini, pa je u poslednjoj deceniji njihova upotreba u Evropi znatno porasla. Ipak, usled negativnih uticaja zapadnog načina ishrane na kardiovaskularni sistem koji su uglavnom povezani sa unosom velikih količina zasićenih masnih kiselina i natrijuma, postalo je neophodno označavanje sadržaja soli i zasićenih masnih kiselina na deklaraciji proizvoda. Poslednjih godina industrija prerade mleka je, u cilju brzog unošenja ove informacije na etiketu mlečnog proizvoda, uspešno razvila i primenila NIRS model predviđanja za linijsko i jeftino određivanje sadržaja minerala i masnih kiselina u komercijalnim sirevima. Razvoj MIRS i NIRS modela za karakterizaciju mleka i sireva je otvorio nove mogućnosti u oblasti prerade mleka, od genetičkog odabira pa do povećanja tehnološke efikasnosti.
(PREGLEDNI RAD) UDK 637.1:543.42

Ključne reči: infracrvena spektroskopija, mleko, sir, novi fenotipi, industrija prerade mleka 